mals. Hitherto the entire emphasis has been on eliminating feral animals. It is also commonplace in other parts of the world for feral animals, particularly goats, to be classed as pests and exterminated whenever and wherever it is possible to do so. However, views upon this are changing both within New Zealand and in other parts of the world. IUCN itself has now recognised that feral animals within particular taxonomic groups may be of value and may be worthy of some conservation action. The SSC has set up a working party on feral animals to review the topic and how to deal with feral animal populations in all parts of the world. This interest within IUCN is matched by recent activities from $F A O$ in which rare and endangered breeds including feral animals have been documented.

In the past, New Zealand has been celebrated for the action which it has taken against introduced mammals. It may now be that the country will be

\section{Humpback Sightings in Antarctica}

\section{Nigel Bonner}

Because of their coastal habits and lethargic nature, humpback whales Megaptera novaeangliae have been among the species hardest hit by the whaling industry. Between 1904 and 1973 (when humpback catching finally ceased), 68,294 humpbacks were reported killed in Antarctic waters, more than 40 per cent of these in the first ten years. Humpbacks, which are relatively easy to identify at sea, have been reported from the Antarctic in recent years only rarely. However, it now seems that some recovery may be taking place.

Last Antarctic summer (1980-81) I made 28 humpback sightings from RRS Bransfield, of the British Antarctic Survey, while working on the west coast of the Antarctic Peninsula in the neighbourhood of the Grandidier Channel and the Gerlache Strait. Because the ship was not celebrated for the lead which it is taking in the conservation of certain feral animals. Already a reserve has been created on one of the off-shore islands for a remnant of a feral sheep population, and management plans will be drawn up which will take account of feral populations on other off-shore islands, some of which are nature reserves. Preliminary studies by scientists are indicating that these isolated remnants of domesticated stock which have been abandoned show interesting features when compared with commercial flocks and herds. This scientific work will be continued at the same time that managers seek solutions to the problem of accommodating alien browsing mammals within the system of nature reserves for the protection of native flora and fauna.

Dr M.R. Rudge, Ecology Division, Dept of Scientific and Industrial Research, 66 Bloomfield Terrace, Private Bag, Lower Hutt, New Zealand.

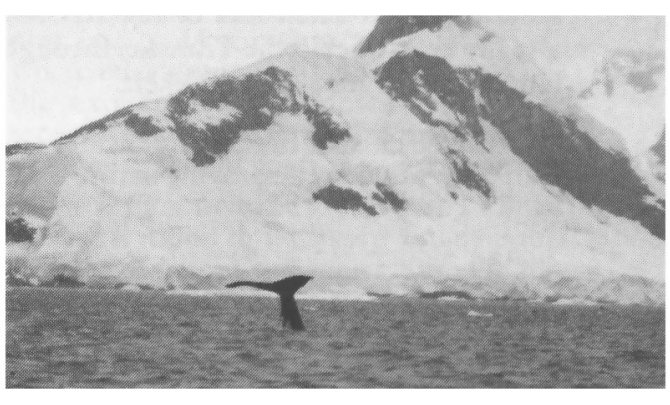

steaming evenly, and I had other duties, it was not possible to make quantified observations from standard watches.

Humpback whales were first sighted on 17th March just to seaward of the Cruls Islands $\left(65^{\circ} 9^{\prime} \mathrm{S}, 64^{\circ} 34^{\prime} \mathrm{W}\right)$ and between 15.40 and 17.00 six were seen, two pairs and two single individuals. Two days later nine sightings were made, in three groups of three whales each. Each group consisted of a large whale, closely accompanied by a smaller one, with another large whale some tens of metres away. Two of these groups were watched swimming northwards along the Grandidier Channel from Cape Tuxen. The third 
group was spotted about half way from Cape Tuxen to the Argentine Islands. This group did not appear to be swimming in a definite direction, but made off north when approached by a dinghy.

On 21st March in the Errera Channel (a narrow waterway leading off the Gerlache Strait), just off Danco Island, humpbacks were in sight more or less continuously while the ship lay at anchor between 10.30 and 16.00. There was a lot of ice about and it was not possible to keep individual groups under observation for long periods. However, 13 whales were logged: one group of 3 going south; two groups of 2 going south; and a single whale going south; one group of 3 going north and one group of 2 going north. It is possible that some the animals or groups were sighted more than once. As in the Grandidier Channel, the groups of three were each composed of two large whales and one small one.

Although it was not possible to make worthwhile estimates of the lengths of the whales seen, I believe that in the case of the trios, the large whale which was closely followed by the smaller one, represented mother-calf pairs. If each sighting represents a separate animal, the 5 presumed calves seen represent about 18 per cent of the total observed, an encouraging indication of the regeneration of the stock.

\section{The Giant Golden Mole}

\section{Walter Poduschka}

The South African giant golden mole has been seen by few people; scientifically it is almost unknown. After two visits to South Africa to look for it, in 1978 and 1980, the author, who is Chairman of the IUCN/SSC Insectivore Group, fears that it may already be extinct in the Transkei through loss of its forest habitat, and that the same fate is to be feared in the Ciskei.

Another black spot in the long history of mankind ruthlessly destroying nature is at hand. The fate of the giant golden mole Chrysospalax trevelyani of South Africa is not only precarious but probably beyond hope; another member of the most basic mammalian group, the Insectivores, will soon be gone. Hardly anything is known about its biology, hardly anybody has ever seen it alive. The only existing photographs of a live specimen were taken by an animal dealer - and nobody knows what happened to the specimen. Probably its remains are in a private collection. So, only a drawing can give an impression of this strange animal, old as the hills.

More than 100 years ago, in 1875 , the giant golden mole was described by $\mathrm{A}$. Günther, who wrote that this hitherto unknown animal was brought to a $\mathrm{Mr}$ Herbert Trevelyan who accompanied a shooting-party in the Pirie Forest near King William's Town (British Caffraria) and believes that it must be very scarce or local, as none of his companions had ever seen another specimen. As far as we know, this mole lives only in dense, relatively humid primary forests, unlike its nearest relative, $C$. villosus, which occurs also in grassland.

It is about $20 \mathrm{cms}$ long, has a dense, reddish-brown fur with a peculiar metalic glimmer, and a slate grey or yellowish underfur. The eyes are reduced and covered by fur, the molars zalambdodont (triangular), which indicates a close relationship to some other African living fossils, the Malagasy tenrecs and the otter shrews of Central Africa, Potamogalidae, which also are only to be found in remote areas and are highly endangered. Not many more than $100 \mathrm{C}$. trevelyani skulls or skins exist in collections all over the world. Apart from the South African scientist J. Meester, who kept one specimen for a few weeks (pers. comm.), hardly anyone has studied it live. Very few scientists have investigated it in the Pirie Forest and nobody has done so in those sites nearby where other early specimens 